\title{
ENVIRONMENTAL RISK ALLOCATION IN THE ASSET RATIONALIZATION PROCESS
}

\author{
SCOTT R. MILLER AND KEVIN S. MACFARLANE*
}

\begin{abstract}
Increasing environmental concern is changing the nanure of oil and gas acquisitions and dispositions. Factors such as increased liability, continuing liability, the emergence of a "deep pocket" response to environmental problems, and a growing uncertainty over the potential extent and nature of environmental problems requires lawyers to review current methods of allocating risk. Where appropriate, counsel should build from existing contractual models; but. where necessary they should be prepared to modify existing practices and adopt new' standards in order to deal with increasing environmental liability. An increased emphasis on due diligence, disclosure and contractual accommodation of environmental problems at the time of the acquisition or disposition is believed to be the best approach as it allow's for flexibility, negotiated responsibility and ensures an appropriate level of investigation and recognition of identifiable environmental problems.
\end{abstract}

\section{TABLE OF CONTENTS}

I. INTRODUCTION .................... 95

A. EVOLVING ENVIRONMENTAL CONCERNS ........95

B. RECENT TRENDS IN ENVIRONMENTAL LAW

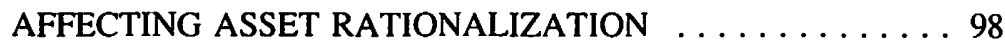

II. IDENTIFICATION OF ENVIRONMENTAL RISKS $\ldots \ldots \ldots \ldots 109$

A. POTENTIAL ENVIRONMENTAL RISK $\ldots \ldots \ldots \ldots \ldots 110$

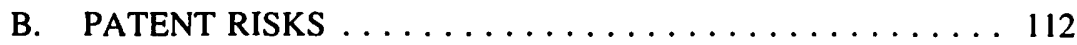

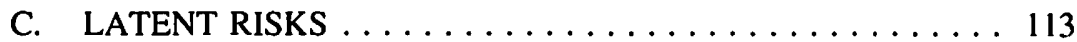

III. ALLOCATION OF NON-ENVIRONMENTAL RISK $\ldots \ldots \ldots 114$

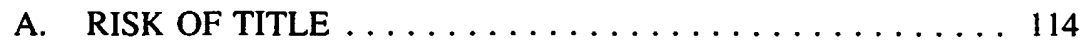

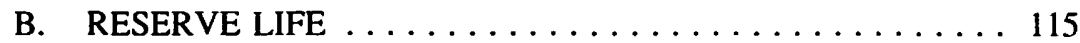

C. DEFECTS IN EQUIPMENT AND

SUITABILITY FOR USE $\ldots \ldots \ldots \ldots \ldots \ldots \ldots \ldots \ldots$

D. CONTRACTUAL OBLIGATIONS $\ldots \ldots \ldots \ldots \ldots \ldots \ldots 116$

E. REGULATORY OBLIGATIONS $\ldots \ldots \ldots \ldots \ldots \ldots \ldots 116$

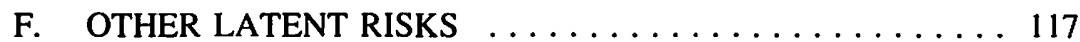

IV. STANDARD METHODS OF RISK ALLOCATION $\ldots \ldots \ldots \ldots 117$

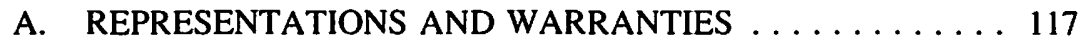

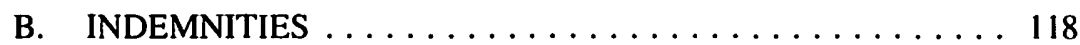

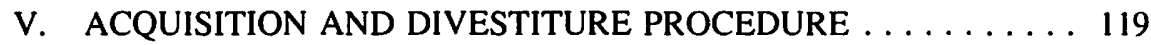

A. DOCUMENT REVIEW $\ldots \ldots \ldots \ldots \ldots \ldots \ldots \ldots \ldots$

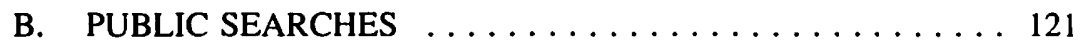

C. VENDORS DISCLOSURE $\ldots \ldots \ldots \ldots \ldots \ldots \ldots \ldots \ldots$

D. SITE INSPECTION $\ldots \ldots \ldots \ldots \ldots \ldots \ldots \ldots \ldots \ldots \ldots$

Barristers and Solicitors, Senior Regulatory Counsel and Manager, Western Canada Land respectively for Petro-Canada. The authors wish to thank Patricia McCunn-Miller, Barrister and Solicitor, General Counsel for the Alberta Petroleum Marketing Commission, for her help in the preparation of this review. 


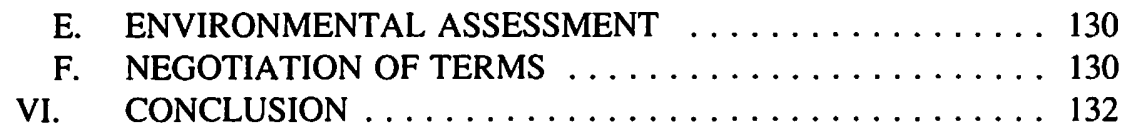

\section{INTRODUCTION}

It is generally accepted that there are risks associated with the purchase and sale of oil and gas assets due to the fact that they may harbour potentially costly environmental problems. The purchaser of such a property may acquire, along with the asset, the opportunity for prosecution under existing or new legislation. The asset may also become subject to control orders, stop orders or other regulatory direction affecting operations and which could require expensive reclamation. Similarly, the purchaser may due to control or ownership become the target of civil action relative to personal or environmental damage. Any of these factors should affect the purchaser's valuation of the transaction or even the decision to acquire the asset itself.

Vendors may also be affected by environmental risks arising as a result of a divestiture. Emerging legislation is tending toward holding parties potentially liable for environmental damage for longer periods of time and, in some cases, indefinitely. Courts are also increasingly willing to find circumstances of "fraud" where potentially detrimental environmental material is not disclosed by the vendor. In addition, the courts also appear to be willing to assess liability to "deep pocket" defendants, such as prior owners, in order to assist in the restitution of environmental damages.

Other parties, such as technical experts and agents, are also discovering that potential liability can arise from their involvement in transactions involving environmentally sensitive properties.

Consequently, the state of the law has developed to the point where acquisitions and dispositions of oil and gas assets should routinely encompass a review of the nature and extent of environmental problems which may arise in order to ensure that these matters are addressed through the best or most appropriate method of risk allocation between vendor and purchaser. Increased sensitivity to environmental concerns is warranted, however, any response must be tempered by the practical need to fairly apportion the risks between the vendor and purchaser in much the same way that non-environmental risks are currently dealt with in oil and gas asset acquisitions and divestitures.

\section{A. EVOLVING ENVIRONMENTAL CONCERNS}

The field of environmental law has undergone a substantial change over the last five years resulting in a general increase in sensitivity to environmental concerns. Rising public interest over the state of the environment has focused public interest, led to strengthened new legislative action and has resulted in enhanced enforcement of existing laws in relation to the environment. Both large scale environmental problems, such as the Exxon Valdez incident, and local concerns such as the discovery of contamination at the former Tricil waste site in Montreal and the leaking of creosote into the Bow River in Calgary have galvanized public opinion and encouraged increased private and public 
response. In the face of sustained public interest in the environment, governments have responded by increasing existing enforcement and by passing new legislation which seeks to manage, control and curtail environmental damage and which also encourages increased public involvement in enforcement. The "public interest" in environmental matters has not been overlooked by the courts who are increasingly weighing public interests against private interests in relation to potential environmental effects. As a result, the oil and gas industry, whose operations frequently have an impact on the environment, will be directly affected by new environmental initiatives.

Increased public interest has already influenced the passage of new environmental laws and encouraged the imminent introduction of others that will have a direct impact on oil and gas operations. The Canadian Environmental Protection Act,' ("CEPA") and the proposed Alberta Environmental Protection and Enhancement Act ("AEPEA"), ${ }^{2}$ are examples of environmental legislation that has, or soon will be, implemented principally due to the public's desire to control the effects of environmental pollution.

Trends in other jurisdictions, although unlikely to have an immediate direct effect on oil and gas operations, are of interest to the industry as a "bell-weather" of things to come in the environmental arena. New legislative initiatives and court decisions concerning environmental matters, emanating from non-producing provinces or from the United States, influence and shape the general environmental law and as a result may eventually have an impact upon the nature of the industry. For example, new legislation such as the proposed Ontario Environmental Bill of Rights may not currently affect oil and gas operations in western Canada; but will, eventually, affect the business practices of financial lenders that are principally located in Ontario and which often play a significant role in the acquisition and divestiture of oil and gas properties. Similarly, legislative initiatives and court decisions involving environmental matters in the United States, although not binding in Canada, may still influence the commercial structure of many oil and gas transactions. Certainly legislative initiatives in California and elsewhere in the United States concerning clean air restrictions have had an impact on both natural gas and oil production and gas refining practices and this in turn, influences the general market and the business decisions concerning asset rationalization. A firm understanding of the existing and emerging environmental law is therefore of assistance both in making decisions concerning asset acquisition and in assessing the likely effect of environmental problems.

Another potential influence on oil and gas practices is the fact that there has recently been a substantial increase in direct public involvement in environmental concerns which has manifested itself in unique and creative ways. Much of this public involvement, including direct intervention at regulatory hearings, court challenges, private prosecutions, public demonstrations and boycotts has the potential to be problematic for oil and gas companies. Notwithstanding the sustained increase in public attention toward the environment, and its manifestation through legislation and public action, the science of

R.S.C. c. 16 (4th. Supp.).

1991 Bill 53. 
environmental remediation has not kept pace with public concern and expectations for a clean environment or in some instances has failed to meet the standards set by new legislation. The industry is therefore caught by more and more stringent legislation and increased expectation without the prospect of clear technological solutions.

All of these factors acting in concert have resulted in a climate of concern and high sensitivity over potential environmental problems on the part of vendors, purchasers, lenders and associated third parties, including the general public. Environmental problems are perceived with uncertainty or concern that they may be too expensive to remediate or control. As a result, transactions are increasingly encumbered with escalating demands and broad indemnities that are not always founded in fact or sustainable in law and which may militate against the orderly rationalization of resource assets and the appropriate allocation of risk between the vendor and purchaser.

Although current uncertainties such as the introduction of new, untested legislation, changes in the interpretation of existing environmental laws and uncertainty over the cost and methods for recovery of contaminated assets do present considerable problems, steps can be taken to alleviate concern over environmental factors and promote comfort and reasonable protection in pursuing such transactions. Experience, understanding and familiarity with the likely environmental problems, the specific asset and the effect of the law can alleviate many concerns and reduce the risk associated with the transfer. Similarly, an understanding of the problems and the adoption by industry of reasonable environmental policies, appropriate operating and divestiture procedures, and rational methods for dealing with these evolving concerns will also assist in relieving concern over oil and gas acquisitions and dispositions.

Indeed, the oil and gas industry as a whole, and legal practitioners in particular, are being compelled by outside interests to develop appropriate reasonable procedures and safeguards to account for potential environmental liability. Other industries and professions are dealing with similar challenges arising due to environmental concerns. The Canadian Bankers Association has acted to prepare guidelines which require agent banks to undertake inquiries and seek disclosure of environmental liabilities in relation to loans and secured transactions. Similarly, the Canadian Institute of Chartered Accountants ("CICA") has included in its practice handbook, requirements to properly deal with environmental problems, including methods for the appropriate assessment and accounting for future removal and site restoration costs. ${ }^{3}$

The oil and gas industry has not yet established a uniform practice to deal with the allocation of environmental risks between the vendor and purchaser, primarily due to the fact that the law and the potential liability is still evolving. Nonetheless, some practice trends such as increased disclosure, increased information acquisition, creative contractual solutions and contingent remediation programs are increasingly being used to facilitate the acquisition and divestiture of oil and gas properties. As these and future methods of risk 
allocation are influenced and defined by specific and general changes in environmental law, a discussion of some of the recent changes is of value.

\section{B. RECENT TRENDS IN ENVIRONMENTAL LAW AFFECTING ASSET RATIONALIZATION}

A detailed review of the environmental regulation of the Alberta oil and gas industry has been previously dealt with in the Petroleum Law Supplement of the Alberta Law Review $^{4}$ and will not be repeated here. However, there have been some recent and proposed changes in the law which may affect asset dispositions and which therefore merit some discussion.

Despite the fact that most of the recently enacted or proposed environmental legislation has been drafted in order to meet the concerns of a variety of different jurisdictions, the fact is that much of this legislation contains a number of common elements. For example, most of the proposed or recently enacted legislation includes requirements for:

i. increased responsibility for the reclamation of disturbed sites;

ii. mandatory spill reporting;

iii. increased fines and penalties for violations;

iv. direct responsibility for environmental liabilities by officers, directors and employees;

v. profit stripping provisions and provisions designed to recover investigative costs;

vi. increased liability for all parties associated with environmental damages including successors and agents; and

vii. an enhanced role in environmental protection and prosecution by the public.

Specifically, in relation to acquisition and divestitures, the emerging factors that are most likely to affect the nature of a transaction include increased responsibility for the abandonment of wells and the reclamation of contaminated sites, mandatory spill reporting, increased investigative and search powers and the trend toward increasing liability for all parties associated with any environmental damage.

\section{Reclamation of Sites}

Currently in Alberta the Land Surface Conservation and Reclamation Act sets out the requirements and procedures for reclamation of surface lands. The Act requires an operator to carry out any work necessary to reclaim the surface of land to a standard deemed acceptable by the Land Surface Reclamation Council. Once the operator meets the terms of the Act in a manner satisfactory to the Council, a reclamation certificate is issued, to the operator. Until a reclamation certificate is issued no surface lease or right of entry order can be surrendered and therefore the operator's obligations continue.

4. A.J. Hudec and J.R. Paulus, "Current Environmental Regulation of the Alberta Oil and Gas Industry and Emergency Issues" (1990) 28 Alta L. Rev. 171.

s. R.S.A. 1980 , c. L-3, as amended. 
However, once a reclamation certificate is issued it acts to effectively end the reclamation liability of the operator. The Alberta Court of Appeal held in Palley v. Sulpetro of Canada Lid. ${ }^{6}$ that an operator could not be required to perform further reclamation work after a certificate had been issued although it did accept that there was a difference between restoration and reclamation that could result in the payment of enhanced compensation to a landowner.

The proposed Alberta Environmental Protection and Enhancement Act will, if enacted in its current form, substantially change the operator's obligation for continuing reclamation. Part 5 of the proposed legislation, deals with the requirements for conservation and reclamation measures and will replace the current Land Surface Conservation and Reclamation Act. Although this proposed legislation retains some existing provisions, such as the requirement for security deposits and provisions dealing with decommissioning and conservation measures, it also introduces increased operator's liability based upon what the Alberta government has described as the "polluters pay" principle.

Under the proposed Act and proposed regulations operators may bear responsibility for reclamation work for a period of up to five years, and in relation to some specified lands up to twenty-five years after completion of a project notwithstanding the issuance of a reclamation certificate. Section 126 of the proposed Act provides for the issuance of an Environmental Protection Order ("EPO") to enforce such further clean-up or reclamation:

126(1) When. after a reclamation certificate has been issued under section 121 , the Director is of the opinion that further work may be necessary to properly conserve and reclaim the specified land to which the certificate relates, the Director may cause an inspector to conduct a reclamation inquiry in accordance with the regulations.

(2) If, following the reclamation inquiry. the Director is of the opinion that further work is necessary to conserve and reclaim the specified land and the work relates to matters that were not apparent to the inspector at the time the inspector issued the reclamation certificate, the Director may issue an environmental protection order regarding conservation and reclamation to the person to whom the reclamation certificate was issued directing the performance of any work that the Director considers is necessary to properly conserve and reclaim the land.

(3) No environmental protection order regarding conservation and reclamation may be issued under this section after the date prescribed in or determined in accordance with the regulations for the purposes of this section, but in such a case the Director may carry out any work that, but for this section, could have been ordered in an environmental protection order regarding conservation and reclamation.

The costs of performing work under subsection (3) are the responsibility of the Government.

The proposed regulations pertaining to these provisions were set out in a regulatory outline circulated for comment by Alberta Environment in the fall of 1991. They provide 
for five year and twenty-five year periods during which further reclamation work may be required. These provisions of the draft Conservation and Reclamation Regulation state:

Operator Liability after Reclamation Certificate

Section 20

The operator of any activity on specified land defined in section l(q) (i)-(v), (vii) and (viii) shall be responsible for any further reclamation of the specified land that may be required by the Chair for a period of up to 5 years from the date of issue of the reclamation certificate.

Section 21

The operator of any activity on specified land defined in section I(q) (vi) shall be responsible for any further reclamation of that specified land that may be required by the Chair for a period of up to 25 years from the date of issue of the reclamation certificate.

The "specified areas" are defined as follows:

I(q) "specified land" means land that is situated in Alberta and is being or has been used for or in connection with or is being held or has been held incidental to or in connection with

i) the construction, operation or reclamation of the site of a well;

ii) the construction, operation or reclamation of a pipeline, battery or transmission line;

iii) the construction, operation, or reclamation of a mine or pit;

iv) the construction, operation, or reclamation of a waste disposal site or landfill site associated with an industrial activity;

v) the conduct of exploration operations;

vi) the construction, operation or reclamation of any plant;

vii) any activity designated as requiring an approval in the Class of Activities Regulation;

viii) the construction, operation or reclamation of an extra-territorial undertaking;

The Chair is defined in section 1(b) to be the Chair of the Conservation and Reclamation Council and the Director of the Land Reclamation division.

Consequently, most common oil and gas operations will entail continuing operator liability for a period of at least five years after the issuance of a reclamation certificate. With respect to the operation of any "plant," which may include buildings, structures, process equipment, pipelines, vessels and storage, the operator's liability could extend for as long as twenty-five years after a reclamation certificate has issued.

As a consequence these provisions cast in doubt any certainty presently afforded by a reclamation certificate. The value of a reclamation certificate has been seriously compromised to the point where it simply serves to "start the clock" with respect to the period of continuing liability. Both the Canadian Petroleum Association ("CPA") and the Canadian Petroleum Products Institute ("CPPI") have expressed concern with respect to the continuing liability that the operator must bear under this enactment even after the 
granting of a certificate. The CPA and the CPPI have indicated to the Alberta government that a twenty-five year term of continuing liability is too long. The CPPI has raised an additional concern as to whether or not an operator could be held liable to reclaim property as a result of the effect of a successor occupant's activities.

Until these matters are addressed the uncertainty that arises will likely be the subject of allocation of risk between a vendor and purchaser. In the absence of clarification by the government, parties will have to develop reasonable responses to ensure that both the operator and its successor assume only their appropriate proportionate responsibility.

\section{Mandatory Spill Reporting}

Recently enacted and proposed provisions relating to spill reporting should also be considered in relation to acquisitions and divestitures. Often it is advisable for the vendor or the purchaser to undertake, either by themselves or through the use of a technical agent, a general site inspection or detailed environmental assessment of the asset prior to a sale or purchase. Spill reporting requirements may give rise to potential legal obligations on the part of the vendor, purchaser or even a third party and should therefore be contemplated and incorporated into the structure of any transaction.

For example, British Columbia has enacted a Spill Reporting Regulation, ${ }^{7}$ which can impose an obligation to report a spill not only upon the person who controlled the substance but also upon any third party that observed the spill. A "spill" is defined broadly in the regulation to include any release or discharge that is not authorized by the B.C. Waste Management Act, ${ }^{8}$ by a permit approval or order under that Act, or by an approved waste management plan. This definition is somewhat tempered through the provision of a schedule which outlines minimum reporting limits. However, the definition encompasses not only current spills but could also pertain to discharges that have arisen over time but may only recently have come to the attention of any party. Seepage from well sumps, storage batteries or other facilities may arise slowly over time and not be noticed until a detailed inspection is undertaken in contemplation of a sale. In such a case the reporting requirement would be the same as one resulting from a catastrophic spill event which seems inappropriate.

Section 2(1) of the regulation indicates that the party who had immediate "possession, charge or control of a substance" before its discharge must immediately report the spill through the Provincial Emergency Program ("PEP"). Section 2(2) of the regulation places an onus upon a third person to report a spill under certain circumstances. This section provides:

2(2) Where it appears to a person obserning a spill that a report under ss( I) has not been made, he or she shall make the report referred to in this section. (emphasis added)

B.C. Regulation $263 / 90$.

S.B.C. 1982, c.41. 
Knowledge of the discharge and the requirement to report it also carries with it a duty to clean-up the discharge. As a consequence, it is clear that any discharges that meet the definition and that are observed as part of an inspection or audit associated with a sale must be dealt with in accordance with the regulations. A potential purchaser or his agent inspecting an asset may be subject to a reporting requirement if a report is not made by the person controlling the substance. Prior discussion between the vendor, purchaser and any technical agents outlining and assigning responsibilities in this regard would therefore be prudent.

Although the reporting provision contained in the proposed Alberta Environmental Protection and Enhancement Act does not provide for the same third party reporting obligation, it does nonetheless require immediate reporting of unauthorized releases by the owner or a person causing a release. Section 105 of Bill 53 states:

105(1) A person, other than the person having control of the substance, who releases or causes or permits the release of a substance into the environment that may cause, is causing or has caused an adverse effect shall, as soon as that person knows or ought to know of the release. report it to

(a) the Director,

(b) the owner of the substance, where the person reporting is not the owner and knows or is readily able to ascertain the identity of the owner.

(c) the person having control of the substance, where the person reporting is not the person having control of the substance and knows or is readily able to ascertain the identity of the person having control, and

(d) any other person who the person reporting knows or ought to know may be directly' affected by the release.

(2) The person having control of a substance that is released into the environment that may cause, is causing or has caused an adverse effect shall, immediately on becoming aware of the release, report it to the persons referred to in subsection $1(\mathrm{a}),(\mathrm{b})$ and (d) unless the person having control has reasonable grounds to believe that those persons already have knowledge of the release. (emphasis added)

Substance is very broadly defined in section $(1)(w w)$ to mean:

1(ww) "Substance means

any matter that

(A)is capable of becoming dispersed in the environment, or

(B)is capable of being transformed in the environment into matter referred to in paragraph (A)

(ii) any odour, sound, vibration, heat, radiation or form of energy and

(iii) any combination of things referred to in subclause (i) and (ii).

It should be noted that there is no quantification of a minimum amount of a substance that establishes a threshold for reporting. As a result even small spills that arise during normal operations may give rise to a reporting requirement as they may cause an adverse effect. Equally problematic is the requirement for the person having control to report the 
release at a time when the legislation suggests he "ought to know" of the release. Such a determination is highly subjective and may often be impossible to determine.

One of the few cases dealing with the effect of reporting requirements of this nature is the Ontario decision in R. v. Weils Food Processing Limited. ${ }^{9}$ Under the provisions of the Ontario Environmental Protection Act $t^{10}$ and the Ontario Water Resources Conservation Act" there is an express obligation similar to the Alberta and B.C. requirements to report spills and other adverse discharges. Weils Food Processing Ltd. had reported spills pursuant to these provisions. Their notice to the Ministry included details with respect to the nature of the spill.

One of the questions before the court was whether or not the notice requirements offended the principles of fundamental justice as they force a person to "confess" spills and other discharges. The concern was whether or not these "forced confessions" and the information conveyed by such a report could be used to incriminate the person in relation to a substantive offence, such as being responsible for a prohibited discharge. The court found that it was contrary to the principles of fundamental justice guaranteed by section 7 of the Canadian Charter of Rights and Freedoms to require persons to put themselves into jeopardy by providing what amounts to a mandatory confession, unless they were protected from the use of the confession as evidence against them. The judge stated:

It is a desirable goal that notice be required and that the failure to give notice to be an absolute liability offence. I find it surprising that the legislation requiring the giving of evidence does not provide further that compliance would not be admissible against the party giving the notice.... I conclude there is a clear infringement of the Charter.

The effect of this decision is that the reporting of a spill is still necessary and required under the Act, however, the use of the information disclosed in the report may be precluded at trial. As this is a lower court decision, it has yet to be seen as to whether or not it will be followed or even adopted in other jurisdictions.

When discovered, the release of a hazardous substance, pesticide or contaminant, under the proposed Act also requires the person responsible to take all reasonable measures to remedy the effects, remove the substance and restore the environment to a satisfactory condition. Pre-sale or pre-purchase inspections therefore may carry with them the potential for the discovery of problems and the requirement to report and remediate affected sites. The existence of a spill usually pre-dates an asset inspection and would still require action regardless of the sale. However, as an asset review has the potential, and indeed is aimed at bringing these concerns to light, it is prudent to prepare and plan for all of the potential consequences of any pre-sale investigation. 


\section{Increased Investigative and Search Powers}

The general trend in recent environmental legislation is toward increased powers of search and seizure in order to assist government in its environmental investigations and prosecutions. The proposed Alberta Environmental Protection and Enhancement Act provides, under section 187 of Bill 53, for a wide variety of circumstances for warrantless searches which include the power to:

187(1)(a) enter and inspect any place to determine

(i) the extent, if any to which a substance may cause, is causing or has caused an adverse effecl.

(ii) the cause of any adverse effect that may occur, is occurring or has occurred, and

(iii) how an adverse effect may be prevented, eliminated or ameliorated and the environment protected or restored;

(b) enter and inspect any place in which the investigator reasonably believes waste can be found;

(c) enter and inspect any place in or from which the investigator reasonably believes a substance is being, has been or may be released into the environment; enter and inspect any place that the investigator reasonably believes is likely to contain documents related to

(i) an activity or thing that is or is required to be the subject of an approval, certificate of variance, reclamation certificate, environmental protection order or enforcement order under this Act, or

(ii) the release of a substance into the environment;

(e) enter and inspect any place that the investigator reasonably believes is, or is required to be, the subject of or referred to in an approval, certificate of variance, reclamation certificate, environmental protection order or enforcement order under this Act; stop and inspect any vehicle, aircraft or vessel that the investigator reasonably believes

(i) is being operated in contravention of this Act,

(ii) is releasing or has released a substance that causes or is likely to cause an adverse effect, or

(iii) is being used in the commission of an offence under this Act;

(g) stop and inspect any vehicle, aircraft or vessel to ascertain whether it or the manner in which it is being operated complies with this Act;

(h) enter any place for the purpose of carrying out any duty imposed or order or direction made or given under this Act, where there has been a release of a substance;

(i) require the production of any documents that are required to be kept under this Act or any other documents that are related to the purpose for which the investigator is exercising any power under clause (a) to (h).

In addition to the rights of entry provided for in section 187(1), the proposed Act provides extensive ancillary powers in section $187(2)$ as follows:

(2) In the course of exercising powers under subsection (1) the investigator may do any or all of the following:

(a) require that any thing be operated, used or set in motion under conditions specified by the investigator; 
(b) use any machine, structure, material or equipment in the place he is inspecting in order to carry out the inspection;

(c) take samples of any substance or thing:

(d) conduct tests or take measurements;

(c) make copies of or take extracts from any documents referred to in subsection (1)(i);

(f) use any computer system at any place to examine any data contained in or available to the computer system;

(g) record or copy any information by any method;

(h) reproduce any record from data in the form of a printout or other intelligible output;

(i) take a printout or other output for examination or copying;

(j) use any copying equipment to make copies;

(k) take any photographs or audio-video records;

(l) make reasonable inquiries of any person, orally or in writing.

These proposed provisions must be read in light of the limits imposed on warrantless searches by the Supreme Court of Canada in Hunter v. Southam Inc., ${ }^{12}$ and indeed it appears that the proposed Act recognizes this fact because section 191(1) provides for the granting of an order by a Justice of the Court of Queens Bench. This section states:

(1) Where a justice is satisfied on evidence under oath by an investigator

(a) that there is reasonable ground for believing that it is appropriate for the administration of this Act for the investigator to do anything set out in section 187, and

(b) that the investigator may not be able to effectively carry out dutics under this Act without an order under this section because

(i) no person is present to grant access to a place that is locked or otherwise inaccessible,

(ii) a person has prevented the investigator from doing anything set out in section 187 ,

(iii) there is reasonable ground to believe that a person may prevent an investigator from doing anything set out in section 187.

(iv) it is impractical, because of the remoteness of the place to be inspected or because of any other reason, for the investigator to obtain an order under this section without delay if access is denied, or

(v) there is reasonable ground to believe that an attempt by the investigator to do anything set out in section 187 without the order might defeat the purpose of that section or endanger human life or health or the environment.

the justice may issue an order to enter and inspect authorizing the investigator to do anything set out in section 187 and specified in the order for the period of time set out in the order.

(2) The period of time referred to in subsection (1) may not extend beyond 30 days after the date on which the order is made, but may be renewed for any reason set out in subsection (1) for one or more periods each of which is not more than $\mathbf{3 0}$ days. 
(3) An application under subsection (2) may be made before or after the expiry of the period.

(4) An order made under this section may be issued or renewed on application without notice.

Regardless of the common law limits imposed upon search warrants or orders of this nature, there is little doubt that these broad investigative powers will enhance the ability of investigators to carry out thorough searches.

Given the public concern, new legislative action, broader investigative powers such as these and an enforcement record which indicates increased prosecution, there is little doubt that more frequent interaction with environmental investigators is inevitable.

Accordingly, appropriate corrective action arising out of the information disclosed during a pre-sale or pre-purchase inquiry should be undertaken by either the vendor or the purchaser in order to provide for a due diligence defence. The return to the vendor of information gathered by a prospective purchaser in the event the transaction is not completed may also be an appropriate requirement in any offering.

\section{Increased Liability}

Recently enacted and proposed legislation increases the responsibility imposed upon a number of parties with respect to environmental damage and remediation. For example, the proposed Alberta Environmental Protection and Enhancement Act expands the definition of the person responsible for the release of a substance to potentially include principals, owners, agents, receivers, managers and trustees. Section l(ii) of the proposed Act states:

(ii) "person responsible", when used with reference to a substance or a thing containing a substance, means

(i) the owner and a previous owner of the substance or thing.

(ii) every person who has or has had charge, management or control of the substance or thing, including the manufacture, sale, handling, use, storage, disposal, transportation, display or method of application of the substance or thing,

(iii) any successor, assignee, executor, administrator, receiver, receiver-manager or trustee of a person referred to in subclause (i) or (ii), and

(iv) a person who acts as the principal or agent of a person referred to in subclause (i), (ii) or (iii);

This definition is very broad and appears to impose upon previous owners and successors "cradle to grave" responsibility for any release without the opportunity to discharge or satisfy that responsibility. The definition captures all parties that may once have had contact with a substance, though those parties may not, at the current time, have control or ownership sufficient to deal with the substance or its consequences. This is of concern because significant obligations can be imposed upon a "person responsible" through the use of Environmental Protection Orders. As well, the obligations are subsisting and are not transferred with the control of the substance, thereby leaving parties 
potentially subject to indefinite future liability for matters which may be beyond their control.

A similar concern arises with respect to a person responsible for the contamination of a site. The proposed Act provides that a person responsible for contamination will be required to pay for site clean-up. However, at the time of writing, the definition of a "person responsible" has not been specified in either Bill 53 or the proposed regulations. A working group has been proposed to define what is meant by a "person responsible for a contaminated site." The ultimate definition of this term will no doubt have a substantial effect upon current and continuing responsibility for contaminated land which is the subject of an acquisition or divestiture.

It is noteworthy that the Alberta Court of Appeal has accepted a relatively broad view of who may be held responsible for environmental clean-up in relation to a statutory duty. In Panamericana De Bienes Y Servicos v. Northern Badger Oil \& Gas Ltd., ${ }^{13}$ the Court of Appeal overturned a lower court decision which had held that a receiver was required to abandon wells of a bankrupt to the detriment of the secured creditor.

In the Badger case the Alberta Energy Resources Conservation Board ("ERCB") made an order requiring the receiver and manager of the assets of Badger to abandon seven wells owned by Badger at a cost of approximately $\$ 200,000.00$. The receiver had on hand approximately $\$ 226,000.00$ which was subject to a priority claim by a secured creditor. At the trial level the matter was characterized by the court as being a question of debt concerning the relative rights of debtors. The ERCB was held to be a debtor notwithstanding the fact that it had issued an order for abandonment rather than undertaking abandonment itself and then seeking repayment, as it could have under the legislation. The trial judge observed that the Bankruptcy Act had not been amended to deal with "modern social problems of abandonment of contaminated property" and the court held that the priority of the secured creditors under the federal Bankruptcy Act superseded the abandonment order of the ERCB. Accordingly, the receiver was not required to abandon the wells utilizing the monies held for the secured creditors.

At the appellate level the court rejected the categorization of the ERCB as a creditor in this instance and instead focused upon the legitimacy of the abandonment order and the duty of the receiver. Although the court deals with the issues in relation to statutory obligations, the social obligations arising with respect to environmental concerns were not far from the surface of the decision. The court defines the issue on appeal to be "whether the Bankruptcy Act requires that the assets in the estate of an insolvent well licensee should be distributed to creditors leaving behind the duties respecting environmental safety, which are liabilities, as a charge to the public."14

The Court of Appeal held that: 
(i) the ERCB was not a debtor as its abandonment order did not create a debt;

(ii) the Receiver was responsible for the management, operation and care of the debtor's assets;

(iii) the ERCB's abandonment order was a valid exercise of a general provincial law; (iv) the exercise of that law may incidentally affect the Federal bankruptcy power but is not in direct conflict with the Bankruptcy Act; and,

(v) the Receiver was bound therefore to obey the law even though it meant that less money was available for distribution.

Given the extent to which the Court of Appeal has indicated that responsibility will extend, it will be interesting to note how similar remedial orders under the proposed Environmental Protection and Enhancement Act will be interpreted by the courts, especially in view of a broad statutory definition of a "person responsible."

In addition to the expanded environmental liability for parties arising under statute, oil and gas companies, and their financial lenders in particular, should be also mindful of recent judicial trends in the United States that have held financial participants liable for environmental restoration.

The denial of an application for certiorari by the Supreme Court of the United States in the case of Fleet Factors Corp. v. United States ${ }^{15}$ on January 14, 1991 validated an original lower court decision that had held a lender liable for the environmental clean-up costs incurred after the borrower had gone bankrupt. ${ }^{16}$ The lender was found liable as an "owner and operator" of a hazardous waste site pursuant to the provisions of the U.S. Comprehensive Environmental Response, Compensation and Liability Act ${ }^{17}$ ("CERCLA").

In Fleet Factors, the lender secured certain loans to a borrower, Swainboro Print Works, a cloth printing company, through a number of financial instruments including an assignment of accounts receivable and a security interest on all of its equipment, inventory and fixtures. The bank also held an interest in the company's real property pursuant to a deed to secure a debt conveying title to the realty. The company fell into arrears and was subsequently declared bankrupt.

The lender foreclosed on its security interest and upon some of the personal property but did not foreclose on its real property interest. It did allegedly become involved in some of the final financial management of the facility. The lender approved shipments, completed sales, set prices, determined layoffs and undertook many of the company's functions. The lender also hired a third party to conduct a public auction. In preparation for the auction or during the auction, the third party moved material, including drums of what was subsequently determined to be toxic waste and dislodged friable asbestos from the property. 
The U.S. Environmental Protection Agency ("EPA") inspected the facility and identified 700 fifty-five gallon drums of toxic substances. The EPA cleaned up the facility at a cost of $\$ 400,000$ and charged the lender, Fleet Factors, with these costs. The lower court held that it was not necessary for the lender to be involved in the day to day operation or management to be found to be an "owner or operator" liable under CERCLA. Rather, the court held that a secured creditor will be liable if its participation in the management of a facility supports the inference that the lender could have affected hazardous waste disposal decisions if it so chose. The Supreme Court refused to grant a writ of certiorari to overturn the lower court decision.

The decision is of interest because it appears to give strength to the "deep pockets" principle of environmental liability and could impose upon lenders or other secured creditors a role of environmental custodian. It also underscores the fact that lenders will be increasingly interested in the environmental condition of current or prospective assets and may require increased warranties and undertakings from a prospective purchaser seeking financing. The recent steps taken by the Canadian Bankers Association to compel inquiries into environmental matters by its member banks demonstrates the direction that banks are taking concerning environmental matters.

\section{IDENTIFICATION OF ENVIRONMENTAL RISKS}

Having regard to the existing and evolving nature and extent of environmental liability it is evident that the most difficult task arising in relation to an acquisition or divestiture will be the reliable assessment of the current and potential liabilities affecting the assets. This task is increasingly difficult for several reasons:

(i) The potential causes of liability are changing as a result of statutory changes, public awareness and judicial temperament;

(ii) The exact nature or extent of environmental problems associated with oil and gas assets are often difficult to ascertain, delineate or even define;

(iii) Acceptable, appropriate or effective measures to remediate problems are often uncertain;

(iv) The response or requirements of regulators is often impossible to determine with certainty and can fluctuate with public opinion and political pressure;

(v) Laws, standards and regulatory requirements change with time; and

(vi) Establishing the final cost for the remediation of any environmental problem is often a guessing game.

Notwithstanding the difficulty associated with this task, identifying and defining the nature and extent of the problem will clearly become the most important part of the asset acquisition and divestiture process. When environmental problems can be accurately identified, delineated and quantified they can also be effectively addressed, remediated, 
or otherwise accommodated through prior direct action, price adjustment or other contractual provisions. It is when these problems are not acknowledged, identified or assessed that both parties are at the greatest risk.

\section{A. POTENTIAL ENVIRONMENTAL RISKS}

Most oil and gas operators now accept the fact, that when dealing with environmental problems, what you don't know can hurt you. Consequently, a careful review by both parties of all lands and facilities associated with a disposition is essential.

Depending upon the value, nature and sensitivity of the transaction the extent of the review may vary. Any review will likely relate to the operation and condition of the facilities including wells, batteries, plants, pipelines, and compressors as well as the physical condition of the land surface and in some cases, the nature of the sub-surface and the groundwater. The most compelling reason for identifying environmental problems arises due to the fact that there exists a multitude of legal liabilities that can flow from each of these discrete problems. Potential liability for environmental matters can arise as a result of criminal, regulatory or civil liability as the following examples illustrate.

\section{Criminal and Administrative Liability}

Current and proposed statutes impose substantial obligations upon parties and carry hefty fines for non-compliance. The purchase of a property which is not in compliance with existing regulations could result in an order to remedy the problem, potentially at considerable cost, and could also result in a fine or further penalty. As well, a stop order could be issued shutting down operations and interrupting needed revenue. An example of such a problem may be the acquisition of a property that is leaking hydrocarbons from a sump or containment area into a watercourse. Depending upon the precise facts, the leak may be in violation of either a provincial statute such as the Alberta Oil and Gas Conservation Act, ${ }^{18}$ the Alberta Clean Water Act ${ }^{19}$ or the federal Fisheries Act ${ }^{20}$ and could result in a stop order, a control order, a fine or a requirement to remediate.

In addition, it is noted that recent environmental legislation also establishes civil causes of action for the recovery of damages flowing from a violation of the statute. Section 136 of the CEPA, ${ }^{21}$ indicates that any person who has suffered loss or damage as a result of conduct contrary to any provision of the Act can sue to recover their loss or can seek an injunction to prevent any damage. Section 207 of the proposed Alberta Environment Protection and Enhancement Act ${ }^{22}$ sets out a similar civil remedy for the breach of a statutory requirement.

R.S.A. 1980, c.0-5.

R.S.A. 1980, c. C-13.

R.S.C. 1985, c. F-14.

Supra, note 1 at section 136 .

Supra, note 2 at section 207. 


\section{Civil Liability}

The potential for civil liability due to environmental disturbance could arise under almost all of the common law causes of action including nuisance, negligence, strict liability, trespass, riparian rights and deceit.

(a) Nuisance - Any unreasonable interference with another party's use or enjoyment of property could be found to be nuisance. As proof of damages is not a necessary part of a nuisance action, it is often used in environmental cases. Spills, noise, odours and vibrations stemming from a facility or activities on an oil and gas site could potentially be the subject of a nuisance action.

(b) Negligence - Negligence encompasses the demonstration of a lack of reasonable care where injury and damage to others is foreseeable. Acquisitions and divestitures do not normally give rise to concern over the imposition of liability sounding in negligence due to the fact that the party actually causing the damage is held responsible. However, an omission causing injury may also be negligent and could give rise to liability. For example, a purchaser that becomes aware of the presence, on an acquired site, of a fire hazard may subsequently be found negligent if the purchaser does nothing and the hazard causes a fire and damage to adjacent property. The purchaser could be found liable if they knew or ought to have known that the material could cause damage and yet failed to take steps to prevent the damage or to warn neighbours of the risk.

(c) Strict Liability - Evolving from the decision in Rylands v. Fletchers, ${ }^{23}$ this doctrine provides that a person can be held strictly liable for harm or damage for the escape or discharge from his lands of something that by its nature is inherently dangerous. This doctrine is often utilized in preference to a negligence action, due to that fact that fault need not be proven to establish liability. The knowledge of the dangerous nature of the thing and the fact of its escape and resultant damage is sufficient to support an action. As a result, the presence of potentially harmful land fill materials, chemical storage sites, improper recovery of well sumps, the integrity of tankage and flowlines will be of importance in assessing the potential strict liability that could stem from the acquisition of oil and gas assets.

(d) Riparian Rights - An action can arise where the owner or occupier of land adjoining a watercourse experiences interference in the quality or character of that water. The presence of spills or leaks on a site and the proximity to a channelled watercourse may raise concern over the potential liability related to the acquisition of a problematic oil and gas asset.

(e) Deceit - A vendor has a duty to disclose any material latent defects relating to a property of which it is aware. A vendor may be liable in deceit where it 
makes a fraudulent representation expressly or through silence with the intention to deceive another party. The withholding of critical information concerning detrimental factors that might not be revealed through a reasonable inspection may be actionable. Consequently, the withholding of information concerning the poor condition of underground storage tanks or pipelines, contamination of underground water, the presence of buried hazardous material or chemicals are examples of cases that could give rise to such an action.

\section{Contractual Obligations}

As well as potentially being held liable in tort, purchasers may be held liable in contract where they agree to assume obligations originally binding the vendor. The assignment of leases, licences and easements associated with an acquisition may require review to determine any potential liability for clean-up or reclamation that could arise upon the surrender of those interests. As well, vendors must ensure that there has been sufficient candor in any transaction in order to avoid an action based in contract relating to misrepresentation, fundamental breach, mistake or failure of consideration. The sale of land rendered unsuitable for purposes other than oil and gas handling or production due to contaminating operations could result in an action for breach of contract. Such an action could be avoided through disclosure, contractual restrictions on the use, or continuing limits on use stipulated in a lease or a restrictive covenant.

\section{B. PATENT RISK}

Each oil and gas asset is unique and the risks associated with its purchase or sale will depend upon a number of factors including site sensitivity, degree and nature of contamination, surface and groundwater considerations, geology, facility type and risk assessment. Often patent risks can be ascertained through inquiry or inspection. Not all conditions on a site may be obvious to an uninformed observer however, and expert assistance is often required to properly evaluate the condition of oil and gas assets and identify potential problems.

As the nature of patent problems giving rise to risk varies for each facility, site and even with each vendor or service contractor, it is therefore not possible to provide an exhaustive list of the specific items that could lead to environmental problems. Parties should conduct a document review and a site inspection in order to determine the existence and nature of patent risks. In general, these enquiries will contemplate the following:

(i) the existence of documentation describing or assessing observed environmental problems;

(ii) the existence of control orders, stop orders or other similar regulatory action;

(iii) the existence of complaints or spill reports from public and private sources;

(iv) the general condition of the asset; 
(v) an evaluation of the current level of compliance;

(vi) the evaluation of any spills or discharges;

(vii) the presence of any faulty equipment; and

(viii) the potential for any expensive clean-up, decommissioning or waste removal costs.

A review of these reasonably ascertainable items is contained in Part $\mathrm{V}$ of this paper which discusses site inspections in relation to acquisition and divestiture procedures.

C.

\section{LATENT RISKS}

Perhaps more problematic for both the vendor and purchaser are latent defects which may not be readily ascertainable upon a reasonable inspection of the asset. A problem such as the presence and concentration of naturally occurring radioactive materials in drilling liquids and sumps creates an expensive handling and disposal obligation that is not readily obvious through a site inspection and may or may not be within the knowledge of the vendor. Buried hazards such as abandoned waste pits and contaminated sumps may result in future compliance or water contamination problems that were not foreseen at the time of the transfer. These latent defects can result in substantial cost to the purchaser and in some circumstances may give rise to liability on the part of the vendor as well.

Although the philosophy of caveat emptor is still valid, the law has provided for circumstances where the vendor's silence may create problems. Latent defects can result in liability for the vendor who may be found liable for the tort of deceit, where they had knowledge of the latent defect and had an obligation to disclose the defect, yet failed to do so. Unlike patent defects, for which there is no obligation to disclose, there is a different standard for latent defects. In relation to asset dispositions the obligation of a vendor to disclose a latent defect might arise where the vendor has knowledge of a defect which renders the property dangerous in and of itself. For example, in the case of Tuttahs and Tuttahs v. Maciak and Maciak, ${ }^{24}$ the vendor failed to disclose that the water supply had been tainted by gasoline. The court held that the importance of this defect imposed upon the vendor a duty to disclose it. A similar circumstance could easily be foreseen in relation to contamination of groundwater by hydrocarbons due to sub-surface operations.

The law in this area has tended in recent years to move away from the position where nothing short of a fraudulent intent was required to prove deceit. There has been a shift so that now liability can be established where the fact concealed is so detrimental that it amounts to fraud. ${ }^{25}$ 
As well as the potential liability in tort for failing to disclose a latent risk, such a failure may also give rise to rescission of a contract due to an error in substantialibus, due to the fact that the purchaser may have received something different than that which was the intended subject of the contract.

The best precaution to be taken by a vendor wishing to avoid liability for latent defects is to provide candid descriptions of properties and access to background site information. Purchasers should be encouraged to have sites reviewed by their own personnel or experts and reach their own conclusion as to the condition of the asset. The use by the purchaser of its own s:xpert may act to diminish the obligation of disclosure of latent defects on the vendor, although, as discussed, disclosure of any known and pertinent facts may ultimately be the best course for the vendor.

In order to review the allocation of environmental risk it is valuable to discuss the current allocation of non-environmental risk in oil and gas transactions.

\section{ALLOCATION OF NON-ENVIRONMENTAL RISK}

Traditional methods of allocating risk between the vendor and purchaser provide benchmarks against which we can examine the appropriate manner for the allocation of environmental risks between those same parties. Rather than attempt to discuss, in isolation, contractual provisions dealing with environmental risks, the authors believe that it is more useful to build from experience and incorporate what the industry has learned in relation to the contractual allocation of risks related to the ownership of oil and gas properties. There is no doubt that statutorily imposed liability and other special factors pertaining to environmental risk will force parties to modify somewhat their approach to the traditional risk allocation methods, however, much can be gleaned from current practices. Some environmental factors may require both vendor and purchaser to focus more extensively upon the process of due diligence, but they will not require us to abandon altogether traditional approaches to contractual risk allocation.

\section{A. RISK OF TITLE}

In the oil and gas context, risk related to security of the tenancy is, rightly or wrongly, the subject of the greatest scrutiny in asset rationalization transactions today. The "by, through and under" title warranty from the vendor and the due diligence verification of title by the purchaser have become the norm by which the allocation of the risk of title failure takes place. It should also be noted that restriction of the time period within which reliance upon the representations and warranties by the purchaser can take place has become industry practice.

The basis for the development of these "standards" appears to lie in the ability of the vendor to observe the existence of these risks in the course of its operations as well as the ability of the purchaser to observe the existence of these risks through the due diligence title review process. It is important to note that responsibilities in this area are usually shared between purchaser and vendor with the obligation resting principally upon the purchaser to identify title problems arising from the action or inaction of any title holder 
prior to the vendor. Such a procedure should, also be considered in relation to environmental risks.

Unless significant title defects have been revealed to the vendor through the process of unitization or pre-drilling title review, such title problems are reasonably considered to be latent defects until such time as they are revealed to the vendor and purchaser through the pre-acquisition title review process. Upon discovery of same, the parties are entitled to assess the effect of the title deficiencies on the total value of the transaction and either adjust the purchase price, defer closing for title rectification purposes, negotiate appropriate indemnities or terminate the agreement. The process of searching for deficiencies, evaluating those deficiencies and reaching some accommodation, should generally be the same for environmental concerns.

\section{B. RESERVE LIFE}

The remaining life of a petroleum or natural gas reserve is indisputably a latent risk for which the purchaser assumes sole responsibility in the asset rationalization process. The purchaser may require the vendor to provide factual data concerning production levels during a reasonable period prior to the sale so that the basis of the purchaser's reserve life estimate can be verified. Unless the vendor successfully advocates that public registers of this data are a reasonable source for such assurance, a vendor's representation in this regard may be required by the purchaser. Like most representations, however, the most appropriate purpose for including such a representation in the purchase and sale agreement is to provide the purchaser with the opportunity to conduct an investigation of public sources of production data prior to closing and turn what may be a latent misunderstanding into a patent error. Although the discovery of a material misrepresentation would entitle the purchaser to allege the vendor's inability to meet a condition of closing, the parties may elect to amend the terms of the purchase and sale agreement rather than terminate the contract for the failure to meet a pre-closing condition. The same is true for environmental defects which are rendered certain prior to a closing.

\section{DEFECTS IN EQUIPMENT AND SUITABILITY FOR USE}

The suitability of an oil and gas facility to meet the intended needs of the purchaser is something which can only be reasonably assessed by the purchaser. The vendor may be expected to make representations that the tangible equipment forming a significant component of the sale is not the subject of defects other than those normally associated with equipment of that vintage. Similarly, the vendor may be asked to provide a representation that they have has provided the purchaser with access to all files which would normally indicate adverse downhole conditions or the existence of technical problems previously encountered with the equipment. In fact, inclusion of such a representation and strict compliance with it may provide some advantage to the vendor in that it not only provides the purchaser with the opportunity, but also possibly the obligation, to conduct a diligent review of such files as a prerequisite to claiming breach of other representations or warranties. 
In the oil and gas industry, however, damages incurred as a result of defects in equipment usually arise from defects which are not obvious to the operator of the facility prior to the relevant incident. In many situations, even if the defects are alleged to be obvious to the operator's field staff, the vendor in the applicable transaction may not be the operator of the lands and facilities. Consequently, for all practical purposes, risk in relation to the operation of such equipment passes to the purchaser upon closing of most transactions. This may change, however, due to legislation or contract, where the damages attributable to defects in design or construction are found to be in excess of the costs associated with replacement of the equipment or even in excess of the total purchase price. In the environmental arena where a leak or spill from defective equipment can give rise to substantial liability there are compelling reasons to scrutinize this practice.

\section{CONTRACTUAL OBLIGATIONS}

Contractual obligations are the clearest example of a patent risk which the vendor is required to present to the purchaser and obtain the purchaser's acknowledgement before the purchaser is deemed to have assumed the risk. Such obligations may relate to equipment leases, service contracts, surface lease obligations, gas contracts, as well as the capital and operating cost obligations associated with the relevant operating agreements. On the other hand, there are latent risks associated with those contractual obligations which may not be readily apparent to either the vendor or the purchaser at the time the risk passes. Examples of such latent risks include the potential default of the operator or a joint operator of the lands and the inability of the reserves to meet pre-paid gas recovery obligations. Once again, these are matters which the purchaser must consider as a part of the due diligence process.

\section{E. REGULATORY OBLIGATIONS}

The failure of the vendor to meet regulatory obligations prior to the disposition poses risks of a nature which have been discussed at the outset of this paper. A process of due diligence status checks with regulatory agencies to confirm the status of licences and certificates can be supplemented by a representation by the vendor that they have not been made aware of any violation of specified regulatory regimes.

This is true in relation to environmental regulatory concerns as well. Although responsibility for identified violations can be allocated to the vendor or the assumption of responsibility for them by a purchaser, with the consent of the regulator, can be reflected in the purchase price, this current practice has to be continuously reviewed in relation to changes in the emerging regulatory environment. While the emerging attitude of regulators appears to promote continued liability of a vendor, and therefore requires a different response, traditional oil and gas regulatory regimes have in the past promoted certainty through the issuance of regulatory releases such as reclamation certificates. ${ }^{26}$ and through the registration of well licence transfers. ${ }^{27}$ Such a system of certificates is 
not yet in place with respect to emerging environmental concerns and indeed the imposition of continuing liability, especially with respect to reclamation certificates, creates potential problems.

The risk of changes in the regulatory regime are, however, reasonably assumed by the purchaser of the asset as a risk of ownership of resource properties. The regulatory regime may provide particular incentives like the Alberta royalty tax credit, but it is the responsibility of the purchaser to ensure that entitlement to such incentives continues. The risk of discontinuation of such incentives rests with the purchaser. Risk associated with future modifications to production allowables must rest with the purchaser, although past violations are reasonably the subject of a representation and warranty or even an indemnity if an unusual probability of such violation exists. Compliance with health and safety standards rests with the vendor for the period prior to the sale, but any violation of such standards more appropriately rests with the purchaser once they assume operatorship of the lands and facilities. Similarly, responsibility for violation of future environmental regulations reasonably rests with the purchaser who will operate the lands and facilities under the new regime.

\section{F. OTHER LATENT RISKS}

Future prices, future market availability, future royalty obligations, future operating costs and future capital costs are all examples of latent risks which the purchaser assumes notwithstanding the fact there does not exist specific due diligence tools to protect against such contingencies. The purchaser often has to take a leap of faith based upon its confidence in prices, and in its choice of asset mix, as well as its overall confidence in the industry. Some parties have been adversely affected in the asset rationalization process due to misjudgment in this risk assessment, but it may be questioned whether those involved have suffered losses to the extent that many explorationists in the oil and gas industry have. Of course, it may also be questioned whether they were out to seek the same level of reward as the explorationist. The lower expected value of return in the asset rationalization process justifies extra caution in the identification of risks that may yield costs in excess of the price of the property.

In a similar manner, although environmental liability may potentially be very large, it will often still be the subject of a similar decision based upon judgment, skill and the best available information. A similar leap of faith may be required in relation to accepting environmental responsibility, however, it should be noted that it is not just the purchase price which may be at risk, but substantial remediation costs or fines may result from a poor decision concerning environmental problems.

\section{STANDARD METHODS OF RISK ALLOCATION}

\section{A. REPRESENTATIONS AND WARRANTIES}

Limitations upon the effectiveness of representations and warranties for purposes of risk allocation must be kept in mind. In his paper entitled "Fundamental Issues and Practical 
Requirements Affecting the Purchase and Sale of Producing Resource Properties," ${ }^{28}$ Martin Abbott pointed out that the purchaser's ability to claim damages stemming from a breach of a representation subsequent to closing, even within the limitation period, may be jeopardized where reliance upon the representation by the purchaser beyond closing cannot be shown. He states:

... viewing representations and warranties as a risk allocation mechanism can backfire. A representation and warranty will not give rise to a cause of action unless true reliance is placed upon it. There are several ways a court vitiates reliance. If a purchaser in his due diligence discovers that a representation and warranty is not true and closes anyway, then clearly there is no reliance. If a purchaser independently checks a fact and decides solely on the basis of his own checking that a fact is correct, he cannot later allege reliance. There is no reliance if the purchaser did not care whether the representations and warranties were true or not, such as where the purchaser is so eager for the deal that he would have closed whether or not he knew of certain facts. The state of mind of the person alleging reliance is obviously very relevant to the issue of reliance, and any purchaser suing on a breach of representations and warranties must face the risk and uncertainty imposed by such a defence. ${ }^{2 y}$

The message to purchasers is that the mere presence of well drafted representations and warranties may not be sufficient protection in the absence of due diligence risk avoidance. That message is as at least as clear with regard to modern environmental responsibilities as it is with regard to those other more traditional risks related to the ownership of resource properties.

\section{B. INDEMNITIES}

Once specific risks have been identified as a result of the due diligence process or a specific reasonable concern has been identified by the purchaser for which the vendor should reasonably retain responsibility, an appropriate period of specific indemnification by the vendor may be negotiated. However, the continued existence of the vendor is a risk that the purchaser must recognize wherever this approach is taken. In the environmental field where "deep pockets" liability is becoming an increasing fact the continued existence of the vendor or purchaser may ultimately be very important to the other party. As an alternative to this indemnification, the probability that the risk may be realized can be identified by the parties and used to calculate the expected value of the loss for the purposes of deduction from the purchase price. In every case, broad indemnities of unlimited term are inappropriate for both the vendor and purchaser as they often conflict with the vendor's intentions as expressed in the representations and warranties and often provide the purchaser with a false sense of security, thereby inhibiting his due diligence efforts. 


\section{ACQUISITION AND DIVESTITURE PROCEDURE}

If it is accepted that adverse environmental conditions will deteriorate with time rather than improve, it appears logical that the best opportunity to allocate risk is at the time of the transfer. Consequently the most appropriate first step in any proposed acquisition or divestiture is to obtain the best information concerning the nature and extent of any environmental problem. This work can be undertaken by either the vendor or the purchaser, however, in some circumstances it may be beneficial for the vendor to conduct inquiries and facilitate disclosure to avoid a duplication of inquires and to ensure that it has available all relevant information. This can be done before the asset is actually offered for sale and affords the vendor the opportunity to withdraw certain assets or to propose a plan for accounting for problematic conditions when a sale is actually proposed. In some circumstances it may actually prove beneficial for a vendor who identifies serious problems to retain control and not sell an asset. It may be the case that remediation over time under the vendor's control and at its own pace offers the most cost effective response to environmental problems and diminishes the risk of regulatory, civil or contractual liability.

It is noted, however, that the purchaser often has the most direct interest in knowing the full extent of any problems relating to environmental concerns as ultimately the purchaser will be the first party affected in the event there is a subsequent environmental problem. Regardless of which party undertakes the review, a firm grasp of the environmental risk will assist both parties in the negotiation of clear terms relating to the transfer of the asset or ultimately in deciding whether or not to acquire or sell the asset.

It is submitted that identifying problems prior to closing allows the parties to consider a series of options including, negotiating the terms of the transfer to account for these specific problems, excluding the problematic asset or providing for contingent action in the event of a future problem. However, after closing, any options are severely limited and usually amount to accepting responsibility and, if possible, negotiating the cost of clean-up or potentially defending a lawsuit. At worst the problem could result in a regulatory order requiring clean-up with no opportunity for structuring and implementing a cost effective remediation plan. Accordingly, the due diligence review and the vendor's disclosure of information concerning the state and nature of the asset is an essential responsibility of both parties to the transaction.

The following flow chart outlines some of the steps that may be considered as a part of a transaction involving potential environmental problems and includes steps such as a document review, site inspection, environmental assessment, the negotiation of terms of acquisition, the exclusion of problem assets and finally the ultimate decision to acquire or divest or not to acquire or divest. 


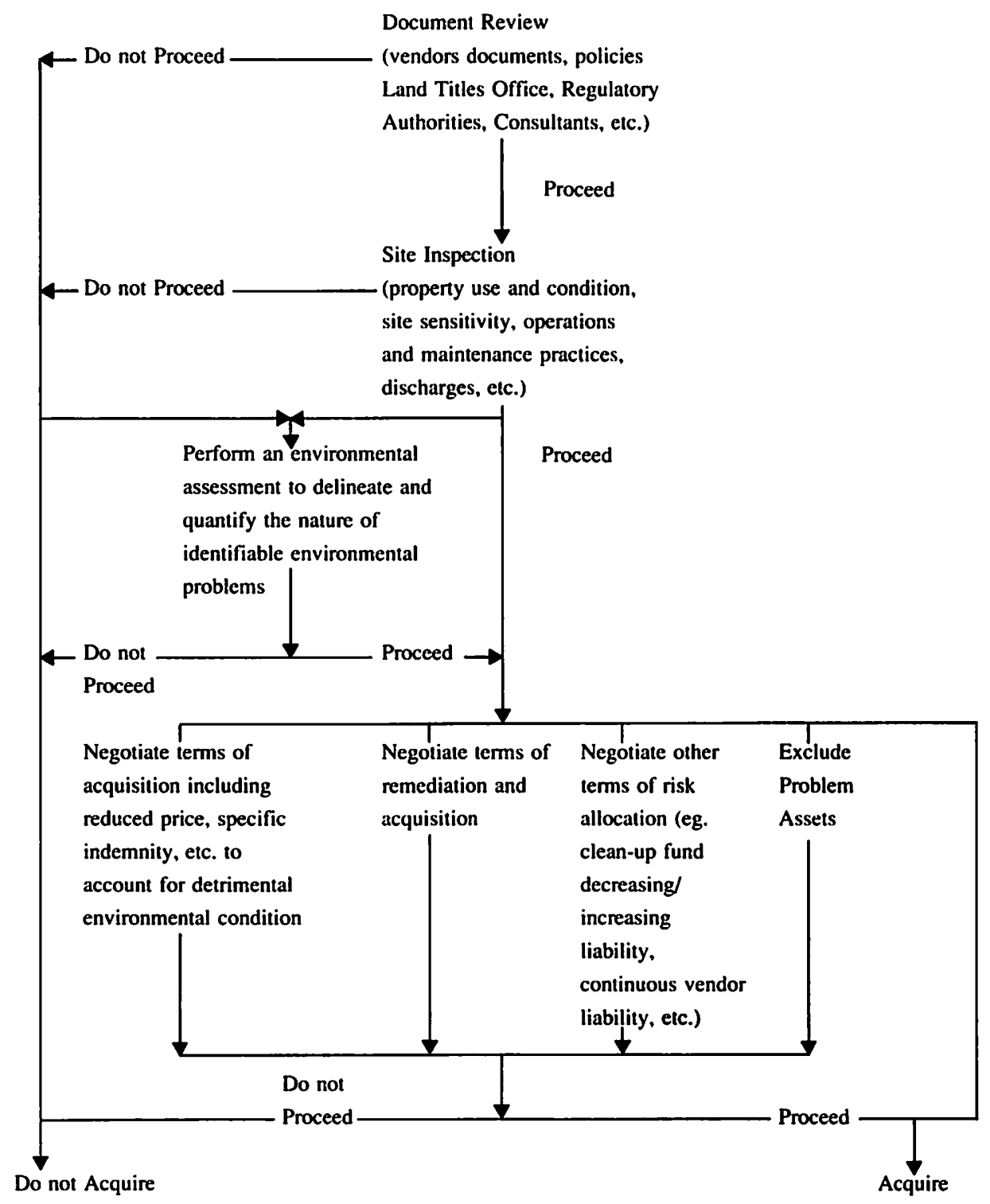

\section{A. DOCUMENT REVIEW}

As identified, the first suggested step in the allocation process will be to perform a document review in order to determine the state of the existing knowledge relating to environmental problems. The document search will normally consist of a review of public information and information available from the vendor, to the extent that the vendor is willing to allow access. 
In Alberta, public sources of information relating to oil and gas assets normally include searches at the Land Titles Office, at the Land Surface Conservation Reclamation Council, at Alberta Environment, at the ERCB or other provincial regulators, and through media searches or local interviews. In addition, the normal searches undertaken with respect to the disposition of oil and gas assets would also be undertaken and would be of assistance in assessing potential environmental concerns.

\section{B. PUBLIC SEARCHES}

\section{Land Titles Office}

A search at the Land Titles Office, including an historical search, can provide information concerning the current owner and insight into the past history of the property. It will also disclose the existence of the any restrictive uses or the existence of a lis pendens or other encumbrance which could suggest an environmental problem. As well, an historical search may provide information concerning the nature or level of activity on the site with respect to both the surface and mineral title. Prior to spending any significant funds an inquiry should be made with the vendor concerning the existence of any title opinions that relate to the properties in question. Often title opinions are available which disclose the chain of title up to a recent period and therefore can provide a convenient source of existing information.

\section{Land Surface Conservation and Reclamation Council}

A search may also conducted through the office of the Land Surface Conservation and Reclamation Council. As indicated previously, surface lands utilized for oil and gas operations may be subject to reclamation obligations under the Land Surface Conservation and Reclamation Act. ${ }^{30}$ If the property is not currently subject to any existing reclamation order, then any party can receive, upon request to the Council, a copy of any reclamation certificate that has been issued. If there are outstanding reclamation obligations then no certificate will be available and inquiries concerning the obligations will have to be made through the owner. The Council will only provide an indication of the outstanding deficiencies where permission is obtained from the actual owner of the land and it may or may not be problematic to obtain such permission depending on whether the vendor is the actual owner of the land or holds some other lesser interest.

Having regard to the proposed changes to the reclamation procedure pursuant to Bill 53, which could extend liability for five or twenty-five years after the issuance of a reclamation certificate, the date of issuance of any certificate will be particularly important. 


\section{Alberta Environment}

Environmental searches can also be conducted through the offices of Alberta Environment. A request to the Compliance Branch, Pollution Control Division of Alberta Environment may result in an indication from the division of any enforcement procedures or violations that have been taken with respect to the owner. Generally, this consists of an indication of any stop orders, control orders, fines or tickets, that have been issued under any provisions of Alberta's current environmental legislation including the Clean Water Act, ${ }^{31}$ the Clean Air Act, ${ }^{32}$ the Hazardous Chemicals Act $^{33}$ and likely the proposed Alberta Environmental Protection and Enhancement Act ${ }^{34}$ when it is passed.

The records are currently arranged by name and therefore the name of the owner and operator must be provided. A search with Alberta Environment is limited in time as records exist only for the period from 1971 onward. Infractions or penalties arising prior to 1971 are not maintained in any easily accessible form. A search can also indicate whether or not the control or stop orders issued by the Department have been withdrawn, although a direct inquiry may have to be made in this regard. Where orders have not been lifted, a discussion with the owner of the facility will be required in order to ascertain the current status of the matter.

\section{Standards and Approvals}

In addition to an Alberta Environment search, a review may be also be undertaken through the office of the Director of Standards and Approvals which maintains a variety of records for facilities licensed within the province. A search with the Director's office will disclose whether the facility is licensed, the act under which it is licensed, and whether or not there have been any violations of the licence. As licenses are drafted having regard to detailed information required by the Clean Air Act or Clean Water Act their provisions may often indicate problematic areas associated with operations. A review of the license applications themselves will also be useful in determining any potential environmental concerns.

\section{Energy Resources Conservation Board Public Registries}

In Alberta, the ERCB maintains a registry of public complaints and outstanding spill reports. The ERCB records are referenced by the name of the licensee or the operator. The list of public complaints will indicate complaints received by the Board for oil and gas facilities where the vendor is listed in Board records as the licensee or operator. The outstanding spill reports contain basic information on complaints addressed to the Board referring specifically to spills or discharges. The complaint registry and the outstanding spills report provide only brief information concerning the existence of a complaint or spill and further details must be obtained either from the appropriate ERCB area office

\footnotetext{
R.S.A. 1980 , c. C-13.

R.S.A. 1980 , c. C-12.

R.S.A. 1980 , c. H-3.

Supra, note 2.
} 
or directly from the vendor in order to determine whether and how the matter was dealt with.

\section{Media Search}

As part of the public searches that should be undertaken as part of any acquisition, a general media review may also reveal relevant environmental information. As the information contained in historical press reports will refer to the owner at the relevant time, information relating to the names of all prior owners of the property or the asset will be required in order to conduct a worthwhile search. Currently, searches of some print media can be undertaken through the use of electronic databases. Unfortunately, the major newspapers in Alberta do not have separate searchable databases that can be accessed by the public. However, the Southam newspaper chain, which operates newspapers in both Edmonton and Calgary, provides for commercial access to its "Infomart" database. As well, some environmental information may be obtained with respect to public companies through a review of annual reports or from the Annual Information Form filed by public companies under the provisions of the Ontario Securities $A c t^{35}$ which require disclosure of material environmental problems.

\section{VENDOR'S DISCLOSURE}

As well as public sources of information the vendor will likely be the most useful source of environmental information, especially where it has in place a formal environmental review and assessment program. Although the amount of disclosure afforded by the vendor may vary, a party that is motivated to sell assets will likely be cooperative in responding to all reasonable requests.

Some of the information that may be acquired from the vendor includes information concerning control orders, stop orders, or other regulatory action undertaken with respect to properties or facilities, permits and permit applications, spill reports and notifications, company policy documents relating to procedures and actions, accident investigation reports, monitoring reports, facility tests, environmental assessments, correspondence with regulators, third party evaluations and engineering studies. All of this information will be of value in assessing and properly negotiating the allocation of risk.

\section{SITE INSPECTION}

Even where the vendor is forthcoming and provides substantial information, such information may not always be up to date or accurate. This is especially true where the assets in question have been inactive or dormant for a number of years. Accordingly, the document review and the information obtained from the vendor are not necessarily a complete substitute for a site inspection. 
In general the information to be garnered from a site inspection relates to the identification and evaluation of patent problems and to the identification of potential latent defects. A site inspection should provide:

(i) a general overview of the condition of the property;

(ii) the identification of site sensitivity and potential problem areas;

(iii) an evaluation of the potential for hidden problems such as sumps or improper disposal sites;

(iv) an evaluation of current compliance;

(v) an evaluation of any onsite or offsite spills or discharges;

(vi) an assessment of the cost of clean up; and,

(vii) an evaluation of discharges into the environment.

Such an inspection provides a "snapshot" of existing conditions and will be utilized to quickly identify problem areas and determine whether a more detailed environmental assessment is required. Although an exhaustive list of potential problem areas cannot be given for each asset, a review of those factors that may be examined in relation to the purchase or sale of a well site may provide an example of the types of practical considerations that should be contemplated. Such a site inspection would include an examination and review of the following matters to ensure compliance with regulatory requirements and to assess the likely potential for liability:

(a) Wellhead Conditions

Check for

$$
\begin{aligned}
& \text { - fluid leaks } \\
& \text { - gas leaks } \\
& \text { - corrosion } \\
& \text { - chemical leaks or spills }
\end{aligned}
$$

(b) Wellhead Vent

Check for

- liquids or gas escaping from a vent that could indicate down-hole problems

(c) Valves and Controls

Check for

- external leaks

- the presence of $\mathrm{H}_{2} \mathrm{~S}$ or other alarm systems 


\section{- ensure alarms are operational}

(d) Valves Secured

On all suspended wells, the wellhead valves should be locked and secured with chain or similar locking device. Suspended or shut-in facilities should also have critical valves secured in order to prevent accidental opening of the valves. A failure to institute precautions could be generally indicative of poor practices and procedures and therefore other potential problems.

(e) Spill on Lease

Check for

-salt water, hydrocarbon or other stains on gravel or soil

-chemical spills

-dead vegetation caused by a spill

- free liquid on the surface or in depressions

(f) Spill Off Lease

Check for

-extent and direction of spill

- sensitivity of surrounding environment (eg. water ways, houses, etc.)

$\rightarrow$ salt water or hydrocarbon stains on soil

-chemical spills

-dead vegetation caused by spill

-suppressed crop growth

-colour variations in vegetation or crop

-disturbed soil from line repairs

-government spill files (ERCB)

(g) Gas Migration

Check for

-dead vegetation

-discoloured soil

-odour of gas

(h) Dyking

Dyking should be used wherever there is potential for spills (eg. around production tanks, chemical storage areas, to isolate natural water or loading or off-loading equipment). The dyke should be of sufficient size in order to contain the total volume of liquid stored.

Check for

-integrity of dyke 
- free of vegetation

-size

-need for additional dyking

release valve condition and position (closed)

-presence, amount and composition of liquids contained in the dyke

(i) Flare Pit Condition

Check for

-integrity of pit walls or containment

- free of vegetation

-composition of material contained, if available

-status of release valves

-history of pit disposal practices, if available

-effect on surrounding vegetation

-presence of surface or run-off water passing through the pit

(j) Lease Condition

Check for

-containment

-contouring (i.e. does it need to be levelled or graded?)

$\rightarrow$ vegetation control or management

- waste disposal and storage

-general aesthetics

(k) Lease Identification

All leases should be identified by use of a proper identification sign pursuant to ERCB requirements.

(l) Fencing

If fencing is required check for:

-integrity of fence

-aesthetics

-locks on gates

(m) Vegetation Management

Check for

-adequate control

-general site condition

-methods used

type of chemical used and appropriate on-site storage if applicable 
history of chemicals used

erosion

-licensed applicator and approved chemical

(n) Access Road

Check for

road condition, all weather access

-grade

-drainage

-vegetation control

-rosion

road spreading of waste sludges, etc.

(o) Erosion Control

Check for

-controls required

-adequacy of methods used

-alternate controls

(p) Chemical Storage

Check for

-dyking

-equipment leaks

-floor wash disposal

-storage methods, do they meet statutory requirements and are they safe?

proper labelling and signage

integrity of pads, building floors, etc.

(q) Fuel Storage

Check for

fuel leakage

registration (eg. under the Alberta M.U.S.T. program)

type of tank, age

(r) Tankage

Check for

-condition and integrity of tank

-dyking free of vegetation

-signs of soil contamination within dyke

-leakage from tanks or valves

-condition of release valve 
type of tank, welded, bolted, fibreglass

(s) Solid Waste Disposal

Check for

-areas free of garbage

-waste storage is adequate

evidence of hidden waste site or improper use of sump

(t) Liquid Waste Disposal

Check for

-disposal options used

-proper analysis when required

$\rightarrow$ spill control

(u) Relief Valves

Check for

-external leaks

-proper storage of released liquid or gas

-spill control

(v) Flare Stack

Check for

-soil contamination in area

-soundness of structure

-spill containment

-location of stack

-ignition system used

-liquid control

(w) Spill Response

Check for

-awareness of employees to the oil spill co-op system

-availability of spill containment equipment

-location of Emergency Response Plan

(x) Building Condition

Check for

-stability of building

floor drains

-cleanliness

$\rightarrow$ ventilation

-construction material (ie. asbestos, wood, etc.) 
(y) Equipment Protection

Check for

-protective pipe isolating potentially hazardous areas

-overhead lines protected

(z) Pipeline Maintenance

Check for

-saltwater or oil spills along right-away

terosion control

-slash disposal

$\rightarrow$ vegetation control

-aesthetics

reclamation methods

-access for inspection or spill clean up

-public access

(aa) Noise

Check for

-noise level surveys

-appropriate signs

(bb) Residences

Check for

-proximity to operating facility

-potential groundwater contamination

-air pollution in area

traffic

-dust pollution

-complaints (especially water problems)

(cc) Wildlife/Livestock

Check for

-protection of wildlife from chemical, salt water, rotating equipment, etc.

-location of equipment relative to wildlife habitat

gates

-dugouts 


\section{E. ENVIRONMENTAL ASSESSMENT}

In the event that the results of the document review, vendor disclosure or the site inspection are not promising or where interested purchasers may, for appropriate business reasons, still wish to acquire an asset notwithstanding poor initial results, the purchaser may wish to perform a more thorough environmental assessment or audit in order to increase its level of understanding relating to the asset and the environmental problem and thereby gain comfort or direction with respect to whether the asset should be acquired or not or whether it should be dealt with in a special manner. Such a review is more detailed than a site inspection and is aimed at the evaluation of a specific environmental problem or concern. The purpose of this type of environmental assessment is to explore, delineate and quantify a specific environmental concern that has been identified through previous reviews. Such an assessment normally concentrates upon specific concerns including surface water analysis, emissions or hazard assessment.

Although such a detailed assessment is normally undertaken by a purchaser, vendors are increasingly considering detailed environmental assessments as a part of the divestiture process due to the trend toward continuing liability for any party dealing with contaminated properties or harmful substances. Vendors scek to use these environmental assessments to establish baseline conditions to support a possible defence against any future regulatory, contractual or civil action. It is used at a later date to demonstrate the state of the property at the time of the transfer and therefore crystallize the liability of the vendor. It can also be used to provide an indication of the degree of any change in the asset condition or contamination from which one can assess relative liability.

As it is aimed at specific concerns, an environmental assessment can also be useful to both parties in determining effective ways to deal with these particular problems. The assessment can provide a more realistic evaluation of the extent of the problem and offer methods for remediation. It may thereby assist in determining whether and how the problem might be dealt with contractually. The assessment could also militate against the acquisition of an asset. If the results disclose that a problem is large, unquantifiable or otherwise problematic, a decision may be made to eliminate that particular property or concern from the transaction or could equally result in the termination of the whole acquisition. It is hoped that the assessment would provide information and comfort to either the vendor or the purchaser sufficient to allow the parties to proceed and accommodate the problem through negotiation and through the contractual allocation of responsibility.

\section{F. NEGOTIATION OF TERMS}

After the reviews, inspections and assessments have been completed, the results should be evaluated with the assistance of expert help. Once environmental problems are identified and quantified they can be effectively addressed, remediated or otherwise accommodated through direct action, adjustment of price or allocation of responsibility through contractual obligations. Depending on the type and nature of the environmental problem there are a number of responses available. As with traditional risk allocation methods, the parties may negotiate the terms of the acquisition or divestiture and agree 
to resolve environmental problems through an adjustment in the price. Similarly, parties may negotiate terms of a contract calling for either the prior or subsequent remediation of the asset by the vendor. The negotiations may also contemplate the exclusion of problem assets altogether in order to promote the sale of other assets.

Increasing environmental responsibility and increasing risk for environmental problems provides an opportunity and incentive for parties to demonstrate creativity in the allocation of environmental risks. The use of creative methods agreed to between parties should be promoted at the time of the transaction. At this stage both parties should be knowledgeable with respect to the nature of environmental problems and equally aware of the obligations imposed by environmental legislation. The parties are, arguably, in the best position that they will likely ever be in order to determine the appropriate action required to accommodate an environmental concern. Armed with knowledge, a number of avenues of redress can be explored by the parties in order to provide flexibility for both the vendor and the purchaser. Such flexibility is not likely to be available at a later date. If the parties do not address concerns at the time of transfer, any subsequent options will be substantially reduced. Therefore identification, discussion, consideration and accommodation of problems through contractual provisions promotes a more appropriate resolution to environmental concerns. Some creative contractual options that may be considered by parties include the following:

(a) A "clean-up fund" could be created to finance the remediation of problematic assets. Variations of the clean-up fund approach contemplate a holdback of a portion of the purchase price, funding through the diversion of a portion of production revenue, the establishment of a bond, or an agreement for contribution into a fund. Normally these provisions contemplate a particular triggering mechanism such as a discovery of a new problem or the delineation of an existing problem, the issuance of an order by regulatory authorities, the commencement of civil action or the occurrence of another identified peril or trigger;

(b) Provision could be made for logically restricting or reducing the extent or the period of liability. Parties have commonly utilized provisions that fix liability to a particular period of time in order to address traditional potential concerns. A variation of this contractual provision is to provide for the progressive shifting of environmental liability from the vendor to the purchaser over time. For example, the use of an increasing/decreasing scale of liability contemplates that the purchaser's liability will decrease over time until it is zero and concurrently the vendor's liability would increase proportionally over time;

(c) A vendor "transfer back" may be contemplated for problematic assets and can be triggered for stipulated reasons;

(d) The purchaser may agree to start, continue or complete a remediation program either before or after the asset has been transferred. In this case specific definition of what work will be undertaken and an agreement on "how clean is clean" will be essential in order to avoid future disagreement. Similarly, the 
parties may agree to a remediation program which is structured to achieve a specific purpose or which will be carried out by one party up to a specified maximum dollar amount; and

(e) The parties may also utilize a specific narrow indemnification, in contrast to broad indemnification provisions, to deal with an identified problem. In general, as in traditional oil and gas transfers, negotiated provisions identifying, fixing or formulating responses to environmental risks are preferable to broad general indemnifications.

These negotiated terms of risk allocation force the parties to ensure that their due diligence and disclosure efforts are thorough. Similarly, such provisions ensure that the parties are diligent in dealing with contemplated or recognizable problems rather than relying upon general contractual terms as a "safety net" for such transactions. It has been noted that such provisions do not necessarily provide the complete protection that parties may originally have thought.

\section{CONCLUSION}

Increasing environmental concern is changing the nature of oil and gas acquisitions and dispositions. Factors such as increased liability, continuing liability, the emergence of a "deep pocket" response to environmental problems, and a growing uncertainty over the potential extent and nature of environmental problems requires lawyers to review current methods of allocating risk. Where appropriate, counsel should build from existing contractual models; but, where necessary they should be prepared to modify existing practices and adopt new standards in order to deal with increasing environmental liability. An increased emphasis on due diligence, disclosure and contractual accommodation of environmental problems at the time of the acquisition or disposition is believed to be the best approach, as it allows for flexibility, negotiated responsibility and ensures an appropriate level of investigation and recognition of identifiable environmental problems. 